\title{
Construction and Implementation of Network Teaching Platform for Design Art Education Based on Cloud Technology
}

\author{
Taiguo $\mathrm{Li}^{1}$ \\ Lanzhou Jiaotong University
}

\begin{abstract}
The campus learning platform based on cloud technology can effectively promote the integration and sharing of educational resources in schools, improve the efficiency of equipment utilization, reduce the application load, and promote the stable and reliable operation of various school applications. Through a detailed analysis of the needs of the campus learning platform, it describes the main problems existing in communication, proposes an overall solution to the education cloud, designs an educational cloud infrastructure platform, and discusses the functional requirements that the system should achieve. The construction process of the teacher resource cloud, student resource cloud, and teaching resource cloud is necessary. Through the test of the learning platform, the system achieves the expected functions and achieves the expected performance. The successful development of the system provides students and teachers with a wide range of independent teaching and self-learning platforms, provides personalized information service functions, effectively achieves the sharing of educational resources, and enhances the level of educational modernization.
\end{abstract}

\section{Keywords}

Network Teaching Platform • Art Education • Cloud Technology • Campus Learning Platform • Cloud Storage

\footnotetext{
${ }^{1}$ Correspondence to: Taiguo Li (MBA), School of Art and Design, Lanzhou Jiaotong University, Lanzhou 730070, China. Email: litaiguo@mail.lzjtu.cn

Citation: Li, T.G. (2018). Construction and Implementation of Network Teaching Platform for Design Art Education
Based on Cloud Technology. Educational Sciences: Theory \& Practice, 18(5), $1738-1746$.
http://dx.doi.org/10.12738/estp.2018.5.073
}


Cloud technology can be divided into 3 types according to its application level and characteristics: public cloud, private cloud and mixed cloud (Hu, 2013; James, Matthew \& Samrachana, 2018; Ren, 2013). The public cloud is a public computing system that provides the underlying solutions and services for the cloud technology. The public cloud does not limit the user, does not belong to any enterprise or individual (Abanda, Tah \& Keivani, 2013; Rezaei, Chiew, Lee \& Aliee, 2014). The private cloud is also called a private cloud. It refers to a large, private, private cloud service developed by an enterprise or a single customer. The private cloud will provide the infrastructure, the server, the network, and the disk as required by the user, and can determine which users are allowed to use them. The hybrid cloud combines the public cloud model with the dedicated cloud model and the provider part of the cloud. Having rights and interests, and sharing it with others through a controllable way, hybrid cloud is the main way of cloud services on the Internet at present (Corbellini, Mateos, Godoy, Zunino \& Schiaffin, 2015). Cloud technology and cloud service will be widely used in various industries (Ren, Li, Yu, Jin \& Robertazzi, 2015). The application prospect of education is very broad. Cloud technology can be applied to teaching management, student communication and management, laboratory construction and management (Wang, Yao, Mitchell \& Gu, 2009).

\section{Cloud Technology Platform Design}

\section{Analysis of application requirements for digital network teaching resources platform based on cloud technology}

The application demand of cloud technology in China's education field is mainly reflected in the following aspects:

(1) Cloud technology has reduced the huge cost of hardware and software in the construction of school basic resources and saved capital. For all kinds of schools in China, both hardware and software investment in daily office or teaching, research and experiment is a huge expenditure. Cloud technology and "cloud services" schools can save 70\%-80\% investment in hardware and software (González-Férez \& Bilas, 2016).

(2) Cloud technology helps educational institutions to share virtual teaching resources and improve teaching level. There is a great difference in the size and investment of all kinds of educational institutions in our network. Therefore, the cloud technology can save the expenses and break the barriers of teaching conditions and environment, so that more teachers and students can use the interconnection.

(3) Cloud technology is conducive to strengthening school teaching management and communication (Zhang, 2017). Teaching management is the key to ensure the quality of teaching and the goal of personnel training. Using the cloud technology platform, the education authorities can strengthen the monitoring of the teaching quality of all kinds of schools, promote the exchange and cooperation between schools, and improve the level of higher education in China .

\section{Technical framework of web-based teaching resource platform based on cloud technology}

The network teaching resource platform based on cloud technology can adopt the leadership of the education department, the participation of cloud service development enterprises, the integrated development model of the public cloud and the private cloud (James, Matthew \& Samrachana, 2018), A.. The cloud technology 
network teaching resource platform needs to build a strong underlying technical support, at the same time, it needs to develop the characteristic functions that meet the needs of the educational institutions. The system technology framework is as follows, as shown in Figure 1 (Drebes, Pop, Heydemann, Drach \& Cohen, 2016).

\section{Hardware and network architecture}

The network teaching resource platform based on cloud technology will provide a unified network and system architecture for educational institutions. It is not necessary for all kinds of schools to configure separate servers and managers, but a centralized management model, and a set of large server systems is only needed in key cities.

\section{The overall functional framework of the teaching resource platform based on cloud technology}

The teaching resource platform based on cloud technology provides a powerful resource integration function. Its technical platform uses layer cloud technology architecture. Its bottom is the infrastructure layer, providing $\mathrm{S}$ cloud infrastructure services such as computing, storage, and so on.

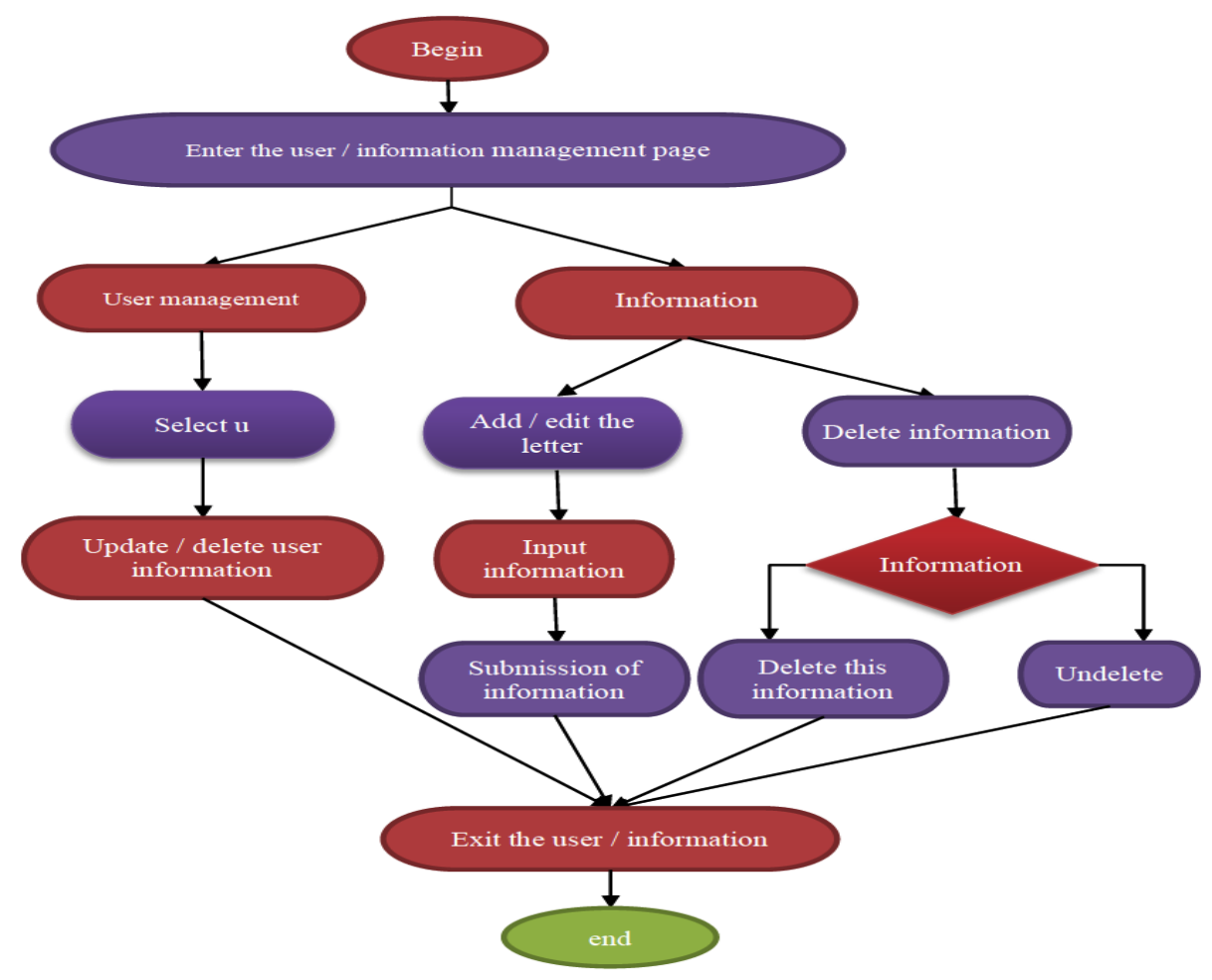

Figure 1. Flow chart of the login system.

\section{Application planning of web-based teaching resource platform based on cloud technology}

The network learning platform is shown in Figure 2. 


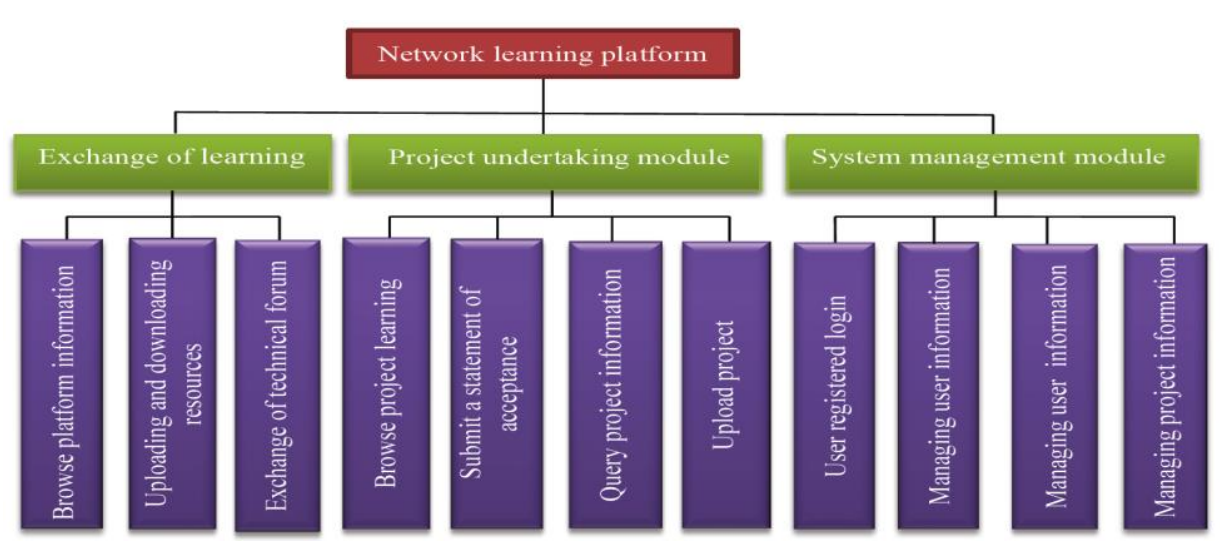

Figure 2. A module diagram of a network platform

\section{Teaching management system based on cloud technology}

If the "software and service" model based on cloud technology is used, all kinds of teaching management software can be used in the form of leasing. The teaching management function of all kinds of schools will be greatly improved. Students can use the "Cloud services": selecting courses, inquiring the grades and credits, class management, and submitting homework. The teachers can use the "Cloud services": record entry, course management, and student flow and so on. Teaching managers can use "Cloud services": student management, student status management, data archiving and processing, etc., so cloud technology services will improve the comprehensive management of teaching affairs, teaching management monitoring, teaching quality evaluation, teaching office process and cooperation for our educational institutions.

\section{Virtual laboratory based on cloud technology}

The so-called virtual laboratory of cloud technology refers to a powerful network running system which integrates the functions of virtual experiment teaching management system, experimental teaching guidance system and network experiment simulation, which can solve the physical experiment course. It will not cause the instrument damage and loss of components caused by improper usage and poor management. At the same time, the virtual experiment can simulate the equipment in the laboratory, and it can also carry out the experiment without the limitation of time and space. Therefore, the virtual laboratory based on cloud technology will provide the first class experimental resources for the ordinary colleges and universities. With the maturity and development of the cloud technology, it only needs to develop some virtual laboratory functions and deploy it on the "cloud serve". All the students can share the use, thus greatly reducing the cost, and improving the middle and low levels. The education quality and teaching level of the level colleges and universities.

\section{Virtual practice teaching system based on cloud technology}

Practice teaching is always the key and difficult point of education. It is difficult to control and evaluate the practice teaching with high cost and strong dispersion. Therefore, it is difficult to carry out and implement a 
large number of schools, which is one of the key factors that restrict the improvement of the quality of school teaching. Through the practice teaching system based on cloud technology, teachers, students and teaching managers can communicate and cooperate across time and space. "Cloud", the teaching and management work of guidance, communication, evaluation, monitoring and so on can be realized in the "cloud end", and even the video practice teaching and management can be realized in the "cloud end".

\section{Platform for educational information collaboration and interaction based on cloud technology}

The improvement of education quality is a whole and systematic project. Communication and cooperation among various schools is an important measure to promote knowledge dissemination and innovation, and to promote resource sharing. Also, there are a large number of interactive exchanges between students.

\section{The Construction of Learning Analysis Model Based on Network Teaching Platform}

\section{The general framework of learning analysis model based on network teaching platform}

Based on the research results of the existing literature and based on the teaching situation of the network teaching platform, this paper puts forward the corresponding overall framework of the learning analysis model, as shown in Figure 3, which contains the core elements of the following four aspect: students, teachers, managers and researchers. Data are derived from behavioral data of middle school students and teachers. According to teaching theory and management theory, data processing is done by statistical methods. Data mining methods provide immediate feedback for students and teachers in order to improve learning and teaching, provide information for the management of the managers, provide support for decision-making, and provide the researchers and teachers' behavior data for the research and teaching.

The learning analysis system is based on the network teaching platform. The data mainly comes from the functional modules of the platform: learning resources, learning, active learning, and so on. The data, teacher data, curriculum data are extracted and stored in special analysis database through cleaning and format conversion. The data collection has reserved the expansion source, which facilitates the subsequent increase of private data, such as the questionnaire, etc., as well as the docking of external data, such as data in social networking sites. The data analysis and processing module mainly deals with the data, and uses component technology to compiling the algorithms of various analysis methods into a callable module, which is stored in the analysis method library, and is easy to reuse. At the same time, it is also beneficial to the continuous expansion of the method library. The rendering module also uses the same method to place various rendering tools in the library. The result feedback module displays the analysis results in a set presentation to the user interface and feedback to students, teachers, or managers in different activities and links in the teaching. In addition, the data collected by the learning analysis system can be directly exported through the data output interface for further analysis by the researchers using other methods. 


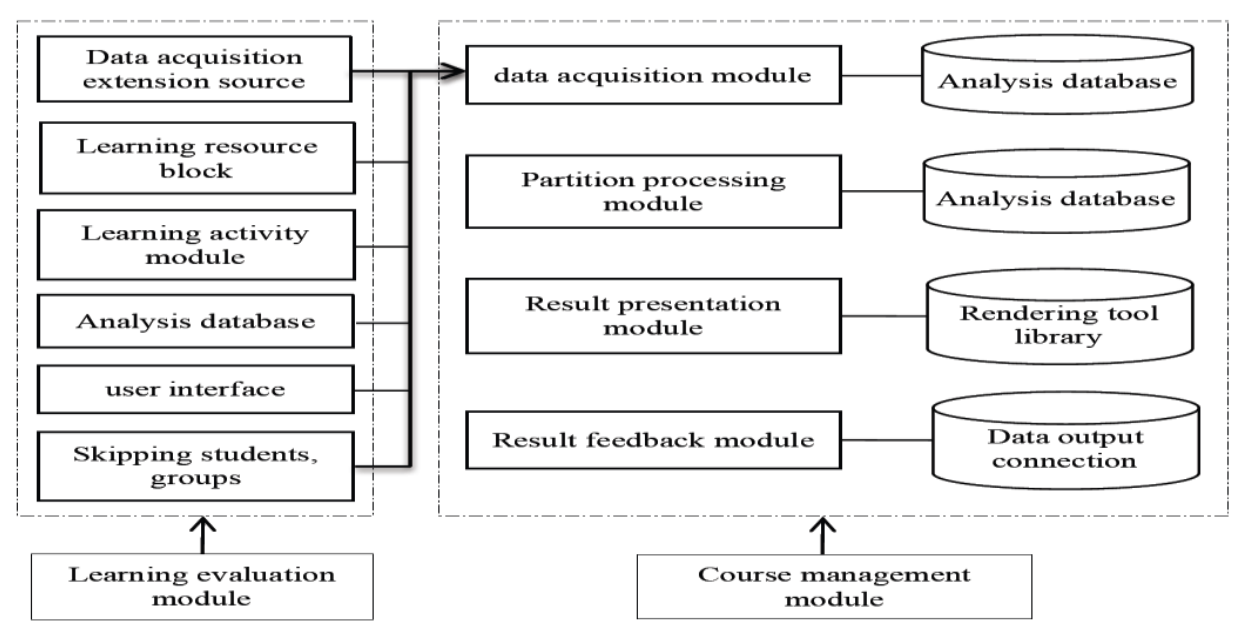

Figure 3. Database and platform connections.

\section{Data acquisition based on learning analysis of network teaching platform}

In the process of data acquisition, it is necessary to consider how to better capture the information of users in a particular situation, such as the time and times of the login system, the task and its frequency, and so on, which can be realized by capturing the information of the PC browser and the mobile terminal App by the students. Based on the need of learning analysis, this paper determines the basic attributes of data acquisition from the network teaching platform, including data name, collection object, data content and collection mode, acquisition frequency and specific source, as shown in Table 1.

Table 1

Data Sources

\begin{tabular}{lllll}
\hline Data name & $\begin{array}{c}\text { Acquisition } \\
\text { object }\end{array}$ & \multicolumn{1}{c}{$\begin{array}{c}\text { Content and method of } \\
\text { collection }\end{array}$} & $\begin{array}{l}\text { Collection } \\
\text { frequency }\end{array}$ & $\begin{array}{l}\text { Specific sources } \\
\text { (network teaching } \\
\text { platform) }\end{array}$ \\
\hline $\begin{array}{l}\text { Curriculum } \\
\text { basic } \\
\text { information }\end{array}$ & Curriculum & $\begin{array}{l}\text { Record basic information of } \\
\text { course, including course title, } \\
\text { course number, class opening } \\
\text { time and so on. }\end{array}$ & $\begin{array}{l}\text { Monthly } \\
\text { Once }\end{array}$ & $\begin{array}{l}\text { Curriculum } \\
\text { management module } \\
\text { (basic information) }\end{array}$ \\
\hline $\begin{array}{l}\text { Course } \\
\text { selection }\end{array}$ & Curriculum & $\begin{array}{l}\text { Record students' names, } \\
\text { names, numbers, their } \\
\text { departments, current status, } \\
\text { etc. }\end{array}$ & $\begin{array}{l}\text { Every day } \\
\text { Once }\end{array}$ & $\begin{array}{l}\text { Curriculum } \\
\text { management module } \\
\text { (students skipping } \\
\text { classes) }\end{array}$ \\
\hline $\begin{array}{l}\text { Students } \\
\text { browse Video } \\
\text { resources } \\
\text { Length of time }\end{array}$ & Student & $\begin{array}{l}\text { Record the time point and exit } \\
\text { point of each click of a video } \\
\text { resource }\end{array}$ & Real time & $\begin{array}{l}\text { Learning resource } \\
\text { module (video) }\end{array}$ \\
\hline $\begin{array}{l}\text { Corrections of } \\
\text { Teachers } \\
\begin{array}{l}\text { Operation } \\
\text { situation }\end{array}\end{array}$ & Teacher & $\begin{array}{l}\text { Record the number and } \\
\text { number of corrections for a job } \\
\text { teacher each time. }\end{array}$ & Real time & $\begin{array}{l}\text { Learning activity } \\
\text { module (homework) }\end{array}$ \\
\hline
\end{tabular}




\section{Data processing and analysis of learning analysis based on network teaching platform}

The content of learning analysis is focused on four aspects: the whole course, the two core parts of the course (teaching resources and teaching activities), the learning unit of the course, the students, and each reusable analysis method component are tagged attributes, including the focus, the analysis content, the required data, the analysis method and the method type. The query is invoked on the basis of these properties. Examples of data processing and analysis are shown in Table 2.

Table 2

Examples of Data Processing and Analysis Based on Web Based Learning Platform Analysis

\begin{tabular}{|c|c|c|c|c|}
\hline Focus & Analysis content & Required data & Analysis method & Method type \\
\hline \multirow{2}{*}{$\begin{array}{l}\text { The } \\
\text { whole } \\
\text { course }\end{array}$} & Curriculum access & \multirow{2}{*}{$\begin{array}{l}\text { (1) the number of } \\
\text { visits of the course: } \\
\text { (2) Access to the list } \\
\text { of users of the course }\end{array}$} & $\begin{array}{l}\text { All courses are ranked } \\
\text { according to total } \\
\text { cumulative visits and } \\
\text { time periods. }\end{array}$ & sort \\
\hline & $\begin{array}{l}\text { The relationship } \\
\text { between the number } \\
\text { of visits and the } \\
\text { time }\end{array}$ & & $\begin{array}{l}\text { The correlation } \\
\text { between the number of } \\
\text { visits and the access } \\
\text { time of a course }\end{array}$ & $\begin{array}{l}\text { correlation } \\
\text { analysis }\end{array}$ \\
\hline $\begin{array}{l}\text { Learning } \\
\text { unit }\end{array}$ & $\begin{array}{l}\text { Students' } \\
\text { participation in unit } \\
\text { teaching activities }\end{array}$ & $\begin{array}{l}\text { (1) the number and } \\
\text { list of students } \\
\text { involved in specific } \\
\text { activities; (2) the } \\
\text { number and list of } \\
\text { elective students }\end{array}$ & $\begin{array}{l}\text { The distribution of the } \\
\text { number of students } \\
\text { involved in all } \\
\text { teaching activities in } \\
\text { the unit }\end{array}$ & $\begin{array}{l}\text { Distribution } \\
\text { description } \\
\text { statistics }\end{array}$ \\
\hline \multirow[t]{2}{*}{$\begin{array}{l}\text { teaching } \\
\text { activities }\end{array}$} & $\begin{array}{l}\text { Test result } \\
\text { distribution }\end{array}$ & \multirow{2}{*}{$\begin{array}{l}\text { (1) all the scores in } \\
\text { the test question; (2) } \\
\text { the number of } \\
\text { students who } \\
\text { participated in the test } \\
\text { and the total number } \\
\text { of elective students. }\end{array}$} & $\begin{array}{l}\text { The highest score, the } \\
\text { upper four percentile, } \\
\text { the median, the lower } \\
\text { four digit, and the } \\
\text { lowest score of all } \\
\text { tests. }\end{array}$ & $\begin{array}{l}\text { A statistical } \\
\text { method of four } \\
\text { division distance }\end{array}$ \\
\hline & Test completion & & $\begin{array}{l}\text { Distribution of all test } \\
\text { submission rates }\end{array}$ & $\begin{array}{l}\text { Distribution } \\
\text { description } \\
\text { statistics } \\
\end{array}$ \\
\hline Student & $\begin{array}{l}\text { The whole learning } \\
\text { situation of the } \\
\text { course }\end{array}$ & $\begin{array}{l}\text { (1) the total number } \\
\text { of activities } \\
\text { completed, including } \\
\text { homework, testing } \\
\text { and video learning; } \\
\text { (2) the total number } \\
\text { of activities in each } \\
\text { category }\end{array}$ & $\begin{array}{l}\text { The distribution of the } \\
\text { completion rate of } \\
\text { various teaching } \\
\text { activities }\end{array}$ & $\begin{array}{l}\text { Distribution } \\
\text { description } \\
\text { statistics }\end{array}$ \\
\hline
\end{tabular}

\section{Presentation and feedback application of learning analysis based on web-based teaching platform}

In the analysis of results presentation and feedback applications, the graphics are more intuitive than ordinary text or data, and the user can easily understand the information contained in the analysis results. Research has built a visual rendering module on Web based teaching platform for teachers to use directly. Based on the characteristics of the analysis of teaching behavior, the demand for feedback and the possibility of presentation of technology, this paper makes a detailed analysis and design of the feedback content and presentation of the results of the learning analysis. The objects of presentation and feedback are mainly students, teachers and managers. Table 3 shows some examples of visualized presentation, such as dial and floating point. 
A graph, a two-dimensional curve, etc. These visual rendering algorithms are compiled into reusable components and placed in the presentation toolkit for users to call at any time. In addition, the data collected by the learning analysis system can be exported directly through the data output interface and fed back to the researcher for further analysis.

\section{Conclusion}

With the rapid development and maturity of cloud technology and application mode, all kinds of "cloud services" have become an important way for the future development of Internet. Reform and innovation are being carried out in the field of education in our country. Cloud technology and cloud service will be widely used in the field of education in our country. Therefore, the platform of teaching resources based on cloud technology will play a great role. In order to establish such a teaching resource platform, first of all, the Department of education should improve the awareness of the application of Internet Science and technology. It is necessary to understand the great integration of the application mode of cloud technology to the educational resources at the high level of the overall development strategy of education. Secondly, we need to carry out scientific research on the application requirements analysis, system construction, technology development and Realization of cloud technology. At the same time, we need to make use of the technical force of the software enterprises to carry out commercial development and operation, strengthen the construction of resources and content, and strengthen the function development of the flat platform of the teaching resources of cloud technology and promote all kinds of educational capital. The development and innovation of the source construction is important.

\section{References}

Abanda, F. H., Tah, J. H. M., \& Keivani, R. (2013). Trends in built environment semantic web applications: Where are we today. Expert Systems with Applications, 40(14), 5563-5577. http://dx.doi.org/10.1016/j.eswa.2013.04.027

Corbellini, A., Mateos, C., Godoy, D., Zunino, A., \& Schiaffino, S. (2015). An architecture and platform for developing distributed recommendation algorithms on large-scale social networks. Journal of Information Science, 41(5), 686-704. http://dx.doi.org/10.1177/0165551515588669

Drebes, A., Pop, A., Heydemann, K., Drach, N., \& Cohen, A. (2016). Numa-aware scheduling and memory allocation for data-flow task-parallel applications. ACM Sigplan Notices, 51(8), 1-2. http://dx.doi.org/10.1145/2851141.2851193

González-Férez, P., \& Bilas, A. (2016). Mitigation of NUMA and synchronization effects in high-speed network storage over raw ethernet. Journal of Supercomputing, 72(11), 1-31. http://dx.doi.org/10.1007/s11227-016$1726-7$ 
$\mathrm{Hu}$, Y. (2013). University public teaching information service platform design and implementation based on private cloud. International Journal of Digital Content Technology \& Its Applications, 7(2), 510-517. http://dx.doi.org/10.4156/jdcta.vol7.issue2.62

James, P. S., Matthew, S., \& Samrachana, A. (2018). Constructing "Experts" among peers: Educational infrastructure, test data, and teachers' interactions about teaching. Educational Evaluation and Policy Analysis, 40(4), 586-612. http://dx.doi.org/10.3102/0162373718785764

Ren, Y. (2013). Design and performance evaluation of NUMA-aware RDMA-based end-to-end data transfer systems. High Performance Computing, Networking, Storage and Analysis, 1-10. http://dx.doi.org/10.1145/2503210.2503260

Ren, Y., Li, T., Yu, D., Jin, S., \& Robertazzi, T. (2015). Design, implementation, and evaluation of a NUMAaware cache for ISCSI storage servers. IEEE Transactions on Parallel \& Distributed Systems, 26(2), 413422. http://dx.doi.org/10.1109/TPDS.2014.2311817

Rezaei, R., Chiew, T. K., Lee, S. P., \& Aliee, Z. S. (2014). A semantic interoperability framework for software as a service systems in cloud computing environments. Expert Systems with Applications, 41(13), 57515770. http://dx.doi.org/10.1016/j.eswa.2014.03.020

Wang, J., Yao, X., Mitchell, C., \& Gu, P. (2009). A new hierarchical data cache architecture for ISCSI storage server. IEEE Transactions on Computers, 58(4), 433-447. http://dx.doi.org/10.1109/TC.2008.166

Zhang, X. (2017). Field composition and development trend of research hotspots of translation technology in China-based on co-word visualization analysis of relevant academic journals from CNKI published from 1999 to 2017. Theory and Practice in Language Studies, 7(12), 1210-1221. http://dx.doi.org/10.17507/tpls.0712.07 